\title{
Afterlives of BBC Radio features
}

Article

Accepted Version

Wrigley, A. (2018) Afterlives of BBC Radio features. Media History, 24 (2). pp. 266-282. ISSN 1469-9729 doi:

https://doi.org/10.1080/13688804.2018.1479636 Available at https://centaur.reading.ac.uk/78362/

It is advisable to refer to the publisher's version if you intend to cite from the work. See Guidance on citing.

To link to this article DOI: http://dx.doi.org/10.1080/13688804.2018.1479636

Publisher: Taylor \& Francis

All outputs in CentAUR are protected by Intellectual Property Rights law, including copyright law. Copyright and IPR is retained by the creators or other copyright holders. Terms and conditions for use of this material are defined in the End User Agreement.

\section{www.reading.ac.uk/centaur}

\section{CentAUR}

Central Archive at the University of Reading

Reading's research outputs online 


\title{
Afterlives of BBC Radio Features
}

\author{
Amanda Wrigley
}

\begin{abstract}
An article published in Media History 24.2 (May 2018),
a special issue on the theme of 'Radio Modernisms: Features, Cultures and the BBC'
\end{abstract}

This essay considers feature programmes written for and first broadcast by BBC Radio networks in the middle decades of the twentieth century which had rich intermedial afterlives following the moment of their first broadcast. ${ }^{1}$ The particular focus is on 'literary' radio features - those taking full advantage of the modernist aesthetics of imaginative radio, often written by established poets and playwrights - published soon after first broadcast by houses such as Faber, Allen \& Unwin and Secker \& Warburg. Repeat broadcasts and new radio productions of features, together with published versions of the scripts, kept these works alive in the minds of listeners beyond the ephemeral moment of first broadcast. When technology and economics permitted the mass circulation of audio formats, sound recordings from the archives could be heard outside of the radio schedule. ${ }^{2}$ In addition, some examples of this most radiogenic of forms have also been, over the years, adapted and realised in other kinds of performance-including staged readings, theatre performances, television productions, films, operas and orchestral concerts. Archival recordings of literary radio features have recently reached new audiences via public listening events held at the British Library where enthusiastic listeners demonstrate sustained interest in examples from this body of work.

These afterlives - re-engagements with radiogenic work across a variety of media over a number of decades - have doubtless helped to construct the sense that there is a central corpus or canon of literary radio features emanating from creative writers and producers working in the mid-century BBC. For those who know something about the output of the BBC Features Department works by established literary figures (such as The Dark Tower and Under Milk Wood) are likely to be amongst those that instantly spring to mind. Scholarly attention has, naturally, been readily attracted to the output of highprofile literary figures, especially when their radio work has been revived and reperformed regularly on radio and has undergone fascinating intermedial metamorphoses (whether in print or other performance forms). Biographers, critics and literary scholars have increasingly come to appreciate that radio features are not an inconsequential dimension of writers' work; rather, they can offer vital clues towards a full understanding of stylistic development. ${ }^{3}$ Historians, too, are interested in the bigger literary names not only for the quality of their radio-writing but also for the weight their radio output adds 
to the general case for radio as a medium worthy of serious study. Much important work has been done, and the valuable links forged between literary scholars and those with a more media historical perspective are mutually enriching.

The fact remains, however, that a good deal of the output of the Features Department remains under-explored, whether as a result of long-term invisibility of works owing to absence of a creative afterlife, the lack of fame attached to the writer's name or issues relating to the preservation and accessibility of archival material. Even Louis MacNeice-whose radio writing has been published, investigated, interpreted and appreciated perhaps as much as, if not more than, any writer of features-was so prolific that scores of his features remain largely unknown. ${ }^{4}$

The output of certain radio-writers has therefore achieved a kind of canonical status as a result of their literary standing beyond radio and because of the (not unrelated) revival and intermedial recirculation of their writing for radio. This essay seeks to illustrate the ways in which the sense of an informal canon of literary radio features may have arisen - for audiences past and scholars present - through an exploration of the rich intermedial afterlives of three literary features: Edward SackvilleWest's The Rescue (1943), Louis MacNeice's The Dark Tower (1946) and Dylan Thomas' Under Milk Wood (1954). First, I outline aspects of the symbiotic relationship between radio and print forms - from the Radio Times, to The Listener, BBC pamphlets, books and libraries. Radio's close relationship with print-as demonstrated in all three examplessuggests that in some sense radio was ephemeral only in theory. Not only did the chronological framing of the audio experience (at least as it was planned up to the moment of printing) leave its trace in published listings (a 'modernist text' in itself, argues Kate Lacey in this volume) and the bare transcript of some features, sometimes with descriptions of sound, exist in magazines or books, but radio programmes were also remembered. They lingered in the imagination, became part of the collective fabric of cultural experience and stimulated the widely held desire for repeated engagements with interesting content. The experience of radio, then, is (or, at least, can be) quite the opposite of ephemeral. It was partly in response to this long-lasting imaginative impact of radio and the appetite it created for repeated or recalled experience that many features made it into the permanence of print. Writers with established relationships with publishers were, it seems, easily able to satisfy their own keen wish to see their radio-writing printed in books and the listener-reader's appetite for features-in-print was strong.

The question of how we may achieve a fuller knowledge of features in this period, one that extends beyond the relatively well-known and accessible works, lies at the heart of this study. The features that have gained a certain profile over the decades, often via re-circulation in different performance forms and media, including print, demonstrate the significance of the form as a site of exploration of contemporary social issues, politics and cultural life. More wide-ranging attention to this protean form, beyond the informal features canon that has accumulated over the decades, may yet reveal much more of significance for social and cultural life of the middle decades of the twentieth century. 


\section{Print Radio}

[...] printed book and radio transcript popularize each other; it is sometimes a two-way traffic. ${ }^{5}$

The relationship between BBC Radio and print was, from the start, symbiotic. The daily schedules published in the weekly magazine Radio Times, for example, were fundamentally important in communicating to the reader, a potential listener, what the BBC planned to broadcast and when. Programme listings were often accompanied by some words or sentences of description and they were sometimes illustrated by photographs or evocative line-drawings to attract the eye and fire the imagination. ${ }^{6}$ The pages preceding the schedules were also used as a space for, inter alia, long-form articles about upcoming programmes: indeed, the first page-length article in the first number of the Radio Times in 1923 was a transcript of a 'recent talk broadcast'. ${ }^{7}$ Radio Times was an incredibly successful publication - indeed, it kept the BBC financially afloat - but its success meant that, as Asa Briggs details, 'the Corporation was involved in frequent quarrels with the press' which viewed broadcasting as a rival. ${ }^{8}$

From 1929, the BBC periodical The Listener offered a new space for printing talks of significance (such as the National Lectures, which began in 1929 with Poet Laureate Robert Bridges) - indeed, its 'primary function [was] to satisfy the constant demands made for the text of broadcast talks after delivery'. ${ }^{9}$ This report of 'constant demands' is evidence for the proportion of the listenership who keenly desired a more permanent record of what they had heard, and the most readily available such 'record' available for circulation at this time was the printed word. Opposition to the establishment of this new journal was strong in the world of publishing, with the leading newspaper associations and societies petitioning even the Prime Minister to intervene to stop it from reaching the printers. The settlement to which the BBC committed stipulated that The Listener take minimal advertising revenue and publish mostly print versions of broadcast programmes; although this did not in practice limit its ambitions and achievements as a thinking person's journal. ${ }^{10}$

As was the case also for the National Lectures, pamphlets were also regularly printed for general talks, libretti and concert 'programmes' for classical music broadcasts. This was akin to the way that the large amount of radio programming for schools from the 1920s regularly relied on the publication, sale and circulation of Aids to Study pamphlets in order to provide essential background, context and further resources for both teachers and schoolchildren to get the most out of broadcasts.

The BBC also published its own books (including its annual 'yearbook') and cultivated strong working relationships with external publishing houses - notably with Penguin. Documentary evidence in the BBC Written Archives Centre and the Penguin Archive suggests that the two often operated hand-in-hand: words heard on the air often were about to be, or had recently been, printed on the Penguin page. ${ }^{11}$ It was common practice for Penguin to send in new titles for distribution to BBC staff; and, over two decades, Allen Lane, the founder of Penguin Books, contributed to a variety of radio 
programmes (for example, a careers programme for schools on the publishing industry in 1947 and a programme on the 21st birthday of Penguin Books in 1956). ${ }^{12}$ In 1969, The Times Literary Supplement considered Penguin to be 'the nearest thing to a BBC-type publishing house impelled by an educative zeal', ${ }^{13}$ a reference to ideological similarities between Allen Lane and John Reith, Director-General of the BBC to 1938.

In more general ways, too, did radio and print reinforce each other's cultural and (self-)educational offerings. Asa Briggs considers that from the 1920s 'more than one local librarian in his annual report referred to wireless as a "new ally [...] creating and deepening the interest of the public in the higher forms of literature" '. ${ }^{14}$ Mark Pegg notes that, although the characteristic informality of the educational effect of broadcasting means that it is difficult to measure its impact with precision, 'radio could provide the incentive to read a book cited in a broadcast: there was evidence that novels dramatised for the radio were quickly put under heavy demand' in libraries. Furthermore, public librarians supported the activities of wireless listening and discussion groups with related book displays and direct sales of BBC publications. ${ }^{15}$

\section{Features on the Page}

Several essays in this special issue of Media History highlight this mutually supportive relationship between radio and print. Indeed, print afterlives of radio feature programmes are a distinctive strand of discussion: for example, Alex Lawrie notes how the 1946 feature programme $A$ Room of One's Own sought to demystify Virginia Woolf for the Home Service audience, encouraging listeners to read the novelist's work-an instance which exemplifies the promotion of reading as an inadvertent consequence of and therefore inseparable from the BBC's broadly educative aims. Lawrie also documents the adaptation of a famed work in print-David Jones' epic poem of 1937, In Parenthesis - into an acclaimed feature, with sound effects, music, drama, as well as verse. Aasiya Lodhi recounts how Louis MacNeice in the 1950s approached Faber (which had already published his poetry and features such as Christopher Columbus and The Dark Tower) with an idea for a 'not too usual kind of travel book' from a selection of the features he had written and produced on overseas topics. ${ }^{16}$ Alex Goody notes how the BBC's arrangement with the Bodley Head in 1940 to publish six episodes of the features series The Shadow of the Swastika (1939-40) pre-empted efforts by staff writers A. L. Lloyd and Igor Vinogradoff to serialise the works in a newspaper or to secure a book contract on their own terms. Goody also writes of how Terence Horsley drew on material forthcoming in his book Norway Invaded, co-authored with James Tevnan, for his radio feature Narvik (1940) and how Cecil McGivern's 1941 feature The Battle of Britain was published later that year by Allen \& Unwin alongside five of his other wartime pieces in the well-illustrated Bomb Doors Open and Other Radio War Features.

In 1950, Laurence Gilliam, the longstanding head of the Features Department, himself edited a book of scripts from fifteen 'outstanding' feature programmes. Published by Evans Brothers Limited, by arrangement with the BBC, it was intended for 'those 
who wish to re-live the enjoyment of a favourite feature and [...] those who were unfortunate enough to miss the programme' ${ }^{17}$ Gilliam's introduction to this volume makes clear that the primary purpose of the collection is to provide 'a more permanent record' of ephemeral radio writing of high quality. He says more about the process of adaptation of sound to print undertaken in his volume:

It may at first seem perverse to attempt to transform material originally created to be heard into material to be read. The test is in the reading. There seemed little point in reprinting these programmes in their original radio scenario form, as prepared for the actors and producer. All the pieces printed here have been rewritten by their original authors at considerably shorter length than the original broadcast. It is hoped that the essence of each has been retained. ${ }^{18}$

Related to the modifications made from script-as-broadcast to feature-as-printed, some items - such as The Man from Belsen (1946) by Leonard Cottrell and British Justice (1947) by Jennifer Wayne-are preceded by an authorial note on the shape, structure and style of the radio broadcast of their work, indicating a desire to offer a stronger sense of the audio experience. ${ }^{19}$

In MacNeice's introductions to his books of radio scripts, several of which were published by Faber, he gives a range of reasons for seeking publication: amongst them is the (clearly common) desire for a more permanent record of his work for the medium, since 'like all radio writers I feel frustrated each time a script has been broadcast', 'because it is "over" '. ${ }^{20} \mathrm{He}$ believes that those he has published are, quite simply, 'worth reading'; but, also, he uses these introductory essays in large part to 'throw some light on the medium', speaking, it appears, to writers who may themselves consider writing for radio. ${ }^{21}$ He notes how the publication of features 'may interest some members of the more literary public in a popular art-form which still is an art-form', alluding, perhaps, to the disdain in which some of the intelligentsia famously held mass media. ${ }^{22}$

The introduction to the 1944 Faber edition of Christopher Columbus is important for MacNeice's nascent thoughts on radio as a medium for creative expression for writers. He emphasises the crucial distinction between writing for readers and writing for radio: for example, 'those subtleties which the ordinary writer uses in rhythm or phrasing - or thought - will often be superfluous and sometimes detrimental to the radio writer'. ${ }^{23}$ In encouraging writers "to forget about "literature" and to concentrate upon sound', invoking the model of the Homeric or Icelandic bard, MacNeice underlines the importance of sound effects and, crucially, music. 'What music can very often do', he considers, 'is to compensate for the lack of the visual element, to establish an emotional atmosphere or to register a change of mood more vividly, and more quickly, than words alone'. ${ }^{25}$ Whereas Gilliam's volume cut down and in other ways adapted its radio works for the page, in his 1947 The Dark Tower and Other Radio Scripts, for example, MacNeice reprinted 'dialogue [...] as broadcast but the directions have been re-written and considerably amplified', to give as much of a sense as possible of the aural experience. ${ }^{26}$ Similarly, in his 1945 Secker \& Warburg edition of The Rescue Edward Sackville-West 
'left the script just as it stood, music cues and all, instead of attempting to refurbish it in the interests of what might seem superior readability', citing 'its suggestive value for other writers' as a motivation here. ${ }^{27}$

Although the vitally important dimension of sound was impossible to reproduce in print, books could (alongside 'directions' and 'music cues') offer additional resources and attractions - paratexts which served to inform, illustrate and contextualise. In addition to the kind of thought-provoking methodological introductions that writers including MacNeice and Sackville-West offered their readers, volumes of scripts published in the mid-twentieth century also offered notes (on e.g. historical background and sources), illustrations (whether visual 'actuality' in the form of historical photographs in Bomb Doors Open and Gilliam's BBC Features, or artistic work such as in The Rescue which, as discussed below, printed six full-page drawings commissioned from Henry Moore). This additional material was far more than could be published in the Radio Times and The Listener before or after broadcasts. Book publication thus gave readers who had heard a feature a stimulating reminder of that experience, together with an enriched context that could be enjoyed even by those who had not been able to 'listen in' to that audio event. ${ }^{28}$ In the 1940s, especially, it is clear that adapted and enriched features scripts were published by those with a degree of literary standing also, in part, as a reflection on the state-of-the-art and as an address to writers who were yet to be persuaded of the potential and power of the form.

\section{'Very close to mike at first, then gradually emerging from the frame': The Rescue's Print and Musical Afterlives}

Novelist and music critic Edward Sackville-West (1901-1965) wrote The Rescue as a radio feature programme whilst on the staff of the BBC in the Second World War. It was broadcast in two parts on 25 and 26 November 1943. The idea for this dramatic feature programme had come from the Director of Music Arthur Bliss who planned to write a radio opera based on Homer's Odyssey. The Rescue was the first substantial creative treatment of Homeric epic on BBC Radio - a truly radiogenic piece. It is modelled on the telling of Odysseus' eventual arrival home on Ithaca after the Trojan War, only to find, and slay, the suitors besieging his wife Penelope, but the characters are developed substantially in line with Sackville-West's desire 'to haul them back from the remote limbo created by the unreal vocabulary of academic translation' ${ }^{29}$ Music was foundational to the conception of the piece and Benjamin Britten (1913-1976) was commissioned to provide a substantial score. ${ }^{30}$ In a half-page Radio Times article, Sackville-West described this radio work as 'not simply a play with incidental music stuffed into the joints or used to add colour here and there, but an attempt to unite speech, song and symphonic music in a form which only the microphone can manage' ${ }^{31}$ Indeed, the collaboration of Sackville-West and Britten made a distinctive exploration of the dramatic potential of radio features. 
In his Radio Times article, illustrated by a poignant drawing of Odysseus asleep in a cave by famed artist Eric Fraser, Sackville-West offers a synopsis of the play, discusses the reason for the focus on this episode in the epic poem and his treatment of the characters, and encourages the reader, a potential listener, to link up the themes of The Rescue with wartime geopolitics. Within two years the text had been published by Secker $\&$ Warburg, prefaced by a ten-page 'Preamble' in which Sackville-West discusses contemporary resonances in greater depth: 'For the startling parallel between the story, as I have told it, and the present state of Greece, I make no apology. It was too obvious to require underlining'. ${ }^{32}$ As noted above, Sackville-West 'left the script just as it stood, music cues and all' which are evocative and revealing of technique: for example, 'Whip cracks and screams of women', 'Distant sound of four Naiads singing' and 'Very close to mike at first, then gradually emerging from the frame' ${ }^{33}$

The volume is illustrated by six full-page drawings especially made by Henry Moore in 1944, four of which were printed in colour and two in black and white. Announcing the 1945 publication in Radio Times, a critic notes that 'the publishers explain that it was outside the scope of this book to print the score, but by way of compensation they offer reproductions of six designs by Henry Moore-the first of his that have appeared as illustrations to a text' ${ }^{34}$ That Moore should have provided these compensatory illustrations is unexpected: he was, of course, primarily a sculptor and classical imagery was for him 'never a dream of a lost idea that might be recovered if only we knew how' but an 'existential classicism, toughened and reduced' ${ }^{35}$ His extraordinary drawings, together with others from his sketchbook for The Rescue, are an important wartime intertext for his Shelter Drawings and his reclining nudes and they continue to resonate, being featured in recent exhibitions such as 'Moore and Mythology' (Henry Moore Foundation, Perry Green, 2007) and 'The Mythic Method: Classicism in British Art' (Pallant House Gallery, 2016).

The 1943 première of The Rescue was followed by at least six new productions on BBC Radio (in 1948, 1951, 1956, 1962, 1973 and 1988). Val Gielgud's 1956 production was one of several feature productions to be showcased in a two-week Festival of Radio Drama broadcast on the Home Service in May. This festival presented 'plays conceived and written for broadcasting over the past thirty years and widely recognised as classic examples of the art of radio drama'. ${ }^{36}$ The fluidity in the terminology here-'radio drama', 'features', 'plays' - was ever thus (see the introductory essay in this special issue), but it is notable that these words, lauding radiogenic features as art, are written by the culturally traditionalist Val Gielgud (head of radio drama and features, later just drama), a staunch advocate of theatre play production on radio. This kind of 'festival' in itself did much to create and maintain the sense of a canon of literary features over the decades, and the selection in 1956 included the usual suspects, such as The March of the ' 45 by the influential producer D. G. Bridson and Louis MacNeice's The Dark Tower.

Fresh attention was paid to Britten's score from 1988, following the radio production by Chris De Souza and Ian Cotterell which featured a five-minute 'interval' reading from Michael De-la-Noy's new autobiography of Sackville-West; ${ }^{37}$ it was immediately followed by Britten's 'Serenade' (Opus 31), composed in 1943 and 
dedicated to Sackville-West. Stimulated by his work on this production, De Souza went on to compile a 45-minute concert version of the music for narrator, soprano, mezzosoprano, tenor and baritone soloists with orchestra, which retained Athene as narrator. This new work, 'The Rescue of Penelope', premièred at Snape Maltings in Aldeburgh on 23 October 1993, fifty years after the first radio broadcast of The Rescue; and Warner Elatus issued a recording of it in $1995 .{ }^{38}$

\section{'...voices dwindle away and a tolling bell grows up out of the distance': The Dark Tower in and out of Print}

Britten also composed the music for MacNeice's The Dark Tower which was written in the spring and summer of 1945 and first broadcast on the BBC Home Service on 21 January 1946. MacNeice dedicated the 1947 Faber edition of the play to Britten and concluded his introduction with the observation that 'Without his music The Dark Tower lacks a dimension' ${ }^{39}$ The protagonist is the young Roland, a reluctant hero sent off by his mother on a quest which he does not comprehend and does not take up readily, his father and brothers having before him set out on the same quest never to return. ${ }^{40}$ This play, written and produced near the end of the Second World War, offers much food for thought on notions of authority, duty, and free will whilst also attempting to do 'justice to the world's complexity': 'I have my beliefs and they permeate The Dark Tower', wrote MacNeice, 'But do not ask me what Ism it illustrates or what Solution it offers. You do not normally ask for such things in the single-plane work; why should they be forced upon something much more complex? ${ }^{41}$ It was a work which immediately appealed across Europe, being translated into French for broadcast in Belgium and France; and, together with his feature The Golden Ass, it was translated into Italian for a production which benefited from MacNeice being present at rehearsals. ${ }^{42}$

As noted in the introduction, above, Louis MacNeice's writing for radio (much of which he produced himself) has received a great deal of scholarly attention. His features are amongst the best known examples of the form, with many of them available in print - and yet, because he was so prolific, a great number of the at least 160 scripts he wrote for broadcast remain largely unknown. ${ }^{43}$ Like many literary figures, he was keen on publishing his features and took advantage of established relationships with editors. Soon after starting at the BBC in 1941, he started offering Faber (which published his poetry) examples from his radio work. In 1942, writing to T. S. Eliot, he mentioned that 'merely on the page' his recently broadcast feature Christopher Columbus 'would read intelligibly and effectively'; Eliot agreed, and it was published in $1944 .{ }^{44}$ In 1945 , he offered more scripts, including The Dark Tower: 'I should of course want to re-write the directions, supplying at least an illusion of the visual element. [...] If you fancy publishing these five in a volume, I can straight away fall to and make a readable version of them' ${ }^{45}$ Accordingly, these were published in 1947. Some fifteen years later, he wrote to Charles Monteith at Faber to ask: 
I suppose you would not be interested in any new radio plays? [...] I was always sorry that, while you have kept both Christopher Columbus and (God help us) Out of the Picture in print, you let The Dark Tower, which I consider much more interesting than either, go out of print. Schools and amateur theatrical societies etc. still keep asking me for permission to give readings or performances of it and I imagine the same would happen with these more recent pieces. ${ }^{46}$

As well as illustrating the easy relationship here between MacNeice and colleagues at Faber, this letter is evidence for the way that The Dark Tower was enjoyed by audiences not just as something heard in successive productions on radio (in 1946, and, for example, in 1950, 1956, 1963, 1966, 1973, 1995 and later), kept in mind and read in book form, but also as something that they may themselves perform. The continuing place of The Dark Tower in the public imagination is illustrated by the 2017 'recreation' of the original broadcast in front of a live audience under the tower of Orford's medieval church, with Britten's music played by the BBC Concert Orchestra, a recording of which was later broadcast on BBC Radio $3 .{ }^{47}$

Further scripts were published in the years following his death in 1963. The Dark Tower was, as was his wish, reprinted in 1964; and in the same year Faber published a volume comprising The Mad Islands (broadcast in 1962) and The Administrator (1961). In 1969 the BBC published Persons from Porlock and Other Plays for Radio. W. H. Auden, who selected the scripts and wrote a Foreword for this volume, based his selection on the criterion that they 'were so well suited to radio that I cannot imagine them being as successful in any other medium' and, to this end, he chose to omit scripts which reworked existing literature by other authors. ${ }^{48}$ In 1993, Alan Heuser and Peter McDonald edited a collection of eight of MacNeice's plays for the Clarendon Press at Oxford: the stated purpose of this volume was to make accessible the texts of some of MacNeice' s best dramatic works, for whatever medium; included were some already published radio works (such as The Dark Tower) as well as some previously unpublished ones (such as Prisoner's Progress, a parable play concerning the Second World War prisoner-of-war camps which was broadcast in 1954 and won second place in the Prix Italia competition of that year).

To this point in the publication history of MacNeice's radio oeuvre, then, the focus was on printing what were perceived to be the best works written for radio by one of the acknowledged masters of the form. In 2013, the latest contribution to his published work took a different approach, exploring the various ways he re-worked one particular and recurrent source of material - Greek and Roman history and literaturefor radio broadcast over the span of his long career at the BBC. ${ }^{49}$ All but one of the eleven scripts in that volume, which I co-edited with classicist Stephen Harrison, had not been printed before: our intention was to expand the known territory and thus get a fuller sense of MacNeice's work in one particular area. Many more of MacNeice's features await similar exploratory attention. 


\section{Under Milk Wood: 'The impression remains'}

The Welsh poet, writer and broadcaster Dylan Thomas (1914-1953) conceived of Under Milk Wood as a piece for performance on radio. Subtitled $A$ Play for Voices, it is a linguistically rich documentary fiction which describes the secrets, longings and regrets of many inhabitants of a Welsh seaside town over the course of a single day through a rich tapestry of narration, dialogue, soliloquy and song. Its joie de vivre and playful mastery of the form are bittersweet in light of Thomas' untimely death shortly before its first broadcast. The BBC Radio production won the prestigious Prix Italia in 1954 as well as a rapturous reception in the press and amongst the majority of listeners who responded to the BBC's audience research survey. The 94-minute radio première was repeated several times: the Home Service broadcast a shortened version later that year; sixty-minute versions were made for overseas services; and it was translated into at least eight languages for international production. New productions commissioned for BBC Radio followed and it remains a popular work to the present day.

It is in terms of radio that Under Milk Wood is primarily considered to be a masterpiece, receiving much critical and academic discussion, but its popular renown derives also from engagements with the work in a range of media following its radio première and its dissemination in both audio formats and in print. Before its first radio broadcast, it was, in fact, performed as a solo reading by Thomas himself in Cambridge, Massachusetts in May 1953, followed by two further readings in New York. After his death six months later further readings and performances were held at the Globe Theatre, the Old Vic, the Festival Hall and the Royal Academy of Dramatic Art.

Douglas Cleverdon, who produced the inaugural radio broadcast in 1954, went on to direct it for the stage with Edward Burnham at the Edinburgh Festival, in the West End and on Broadway across 1956-57. It was at this time common for the BBC to transmit extracts from current theatre productions and for these broadcasts to lead to full television productions. The televising of an extract from one of the Edinburgh performances in 1956 was therefore followed in 1957 by a full BBC television production which, the theatre manager Henry Sherek notes, broke new ground by featuring 'the entire London cast almost immediately after the London closure' ${ }^{50}$ In the years that followed, a second television production was broadcast in the BBC's Festival series (1964); Thomas' play also inspired the Stan Tracey Quartet's 1965 Jazz Suite and, amongst many other cultural engagements internationally, the play was adapted as film (dir. Andrew Sinclair, 1972) and an opera (composed by Walter Steffens, 1973).

Soon after its first broadcast, Decca issued vinyl recordings of the first production under the Argo label regularly from 1954 and recordings of Dylan Thomas' stagereadings in New York in 1953 were released commercially by Caedmon Records in 1956. In 2001 the BBC issued a BBC Radio Collection CD of the 1963 BBC production, including extracts from the first production from 1954. In 2003, BBC Audiobooks released a two- $C D$ set of 'unique extracts from the BBC archives'. Opening with an introduction from Thomas' biographer Paul Ferris, the collection includes readings of Thomas' poetry and prose, as well as an extract from the 1954 radio production of Under 
Milk Wood, its forerunner Quite Early One Morning and Return Journey to Swansea. Most recently, in 2014, Pip Broughton directed a star-studded BBC Wales television production for the centenary celebrations of Thomas' birth and the BBC produced The Road to Milk Wood, an interactive multimedia digital book on Thomas' life and this work in particular, illustrated with an abundance of archival footage and practitioner interviews. Across the decades, then, opportunities to hear Dylan Thomas' Under Milk Wood have been, and continue to be, plentiful.

The play could also easily be read. In March 1954, shortly after Thomas' death, J. M. Dent \& Sons Ltd published Under Milk Wood, an edition of the text compiled by his literary trustee Dr Daniel Jones. New York's New Directions published the American edition the following month. Incomplete and abridged versions had already appeared in the quarterly Botteghe Oscure (Rome, 1952), in the February 1954 issue of Mademoiselle (New York) and in The Observer (7 and 14 February 1954). In the same year, Dent also put into print a volume of twenty-two short stories, sketches and essays from his radio work. Thomas had the idea for this book before leaving for what was to be his last journey to New York; Aneirin Talfan Davies of the BBC Welsh Service edited the collection into shape. 'It is impossible to close the book without regret, without an infinite sense of loss', writes a reviewer in The Times Literary Supplement: 'Dylan Thomas as a broadcaster was unique. His place in sound radio was equivalent to Chaplin's place in the silent film' ${ }^{51}$ In 1958, Dent produced an acting edition, including stage directions and lighting cues from the stage production, and, in 1969, The Growth of Milk Wood, Douglas Cleverdon's account of the eleven significantly different versions of Under Milk Wood, drawing on his close association with both radio and stage productions: 'the process of construction,' he states, 'was hampered, particularly in the later stages, by compromises that were designed to adapt the work for such differing purposes as radio feature, public reading, and stage production'.$^{52}$ Cleverdon's purpose was not to work towards a definitive text of Under Milk Wood, but to 'analyse the textual variations and to trace the complicated - and occasionally hilarious - development of the script' ${ }^{53}$ Further works on Dylan Thomas abound.

Thomas' untimely death-just as Under Milk Wood was coming to life-doubtless gave Under Milk Wood's afterlives added vigour. Its various iterations, through aural performance, commercial recordings, readings, embodied performance, televised productions and film, and the printing of the play in various stages of its evolution in periodicals, newspapers and books, ensured long-lasting renown for this brilliantly impressionistic piece first conceived of as a radio feature. It also serves as a fitting living memorial to the poet's radiogenic expertise and, not inconsequentially, a source of income for the poet's estate. The fact that theatre and television practitioners immediately sought to perform Under Milk Wood as live theatre and pre-recorded television says much about how readily its entertainment potential was perceived, and how much audiences enjoyed the work. In an earlier study, I concluded that the language contemporary critics used in reviews of Under Milk Wood in its various performative incarnations relied heavily on the discourse of fidelity (in which aesthetic value is perceived in inescapably close relation to the distinctiveness of the 
communicative strategies of the first, originating medium - in this case, radio). ${ }^{54}$ The BBC's research report on Under Milk Wood's television audience (at least that proportion of which that was not distracted by perceived immorality or the absence of plot) held a relaxed position, taking the work at face value and judging it in terms of the production's aesthetics and entertainment value. As one critic who deviated from customary concerns over fidelity put it, Under Milk Wood can 'take decoration and expansion without harm. The impression remains'. ${ }^{55}$

\section{Conclusion}

Looking back, in 1982, to radiogenic writing for the mid-twentieth-century BBC, Ian Rodger states that 'Radio bred [...] a generation of writers who knew that they must listen while they wrote', ${ }^{56}$ echoing MacNeice's encouragement of radio writers 'to forget about "literature" and to concentrate upon sound'. ${ }^{57}$ In his introduction to Christopher Columbus, MacNeice argued that music could 'compensate for the lack of the visual element'. ${ }^{58}$ Yet Rodger's proposition is that:

[...] any study of the scripts without being able to hear the recordings must necessarily lead to imperfect understanding. Though the meticulously annotated scripts of writers like MacNeice may appear to describe everything that happened in the studio, they cannot convey the magic which was present when the words, the music and the effects were woven together by the actors, the musicians and the sound technicians. ${ }^{59}$

It is obviously true that that printed versions of the scripts of feature offer a different experience than listening to the orchestration of the different elements of the sound broadcast. But to speak of 'compensation' and 'imperfect understanding' is to measure the worth of printed versions negatively and to lose sight of the advantages. This is not unlike how early radio practitioners and critics continually defined radio in terms of its 'blindness'.

Scripts, transcriptions, adaptations for the page (or however we may describe printed forms of feature programmes) served different constituencies and different ends. ${ }^{60}$ Print enabled writers to achieve a permanent record of and reach wider audiences for their radio work and, in the years of experiment in features' formal aesthetics, radio writers considered it a service to the profession to make their good work widely accessible for their peers. Print also offered opportunities for the enrichment of the aural experience, with historical notes, introductory and interpretative essays, photographic images and illustrative artwork. Clearly, there was a market for them, and a financial benefit to author and publisher. Book-buyers and book-borrowers provided the bulk of the readership and, as we heard from MacNeice, listener-readers enjoyed reading the works, remembering the sound of them and also, for example, enacting them in their communities. 
Offering both less and also more, the printed form of radio features were valuable experiences in themselves and on their own terms. They were also part of a rich cultural back-and-forth, not only between radio and publishing, but commercially available recordings, films, television productions, and so on. Features have had a surprisingly wide reach via their intermedial afterlives, especially considering the form's muchvaunted medium specificity. Some of the more literary and dramatic work, such as Under Milk Wood, has arguably had longer, more complex and textured afterlives than, say, Bomb Doors Open. Their authorial pedigree lends them easily to canonisation. When programming the first, experimental series of public listening and engagement events at the British Library, our inclination to select works with which the potential audience might find some kind of 'hook', via the writer's name, for example, or the work's afterlife, was strong. The first series therefore consisted of The Rescue, The Dark Tower and Under Milk Wood, alongside the radio adaptation of In Parenthesis and The March of the ' $45 .{ }^{61}$ The Radio Times in 1962 declared that 'only The Dark Tower [...] can compare with The Rescue as an original radio piece in literary quality, sensitively imaginative treatment, and brilliant exploitation of the possibilities of the medium': this kind of language, in seeking to pull in the audience, cannot help but promote the sense that, within features, there was a cultural hierarchy in which some work was exceptional. ${ }^{62}$

These masterpieces, as they are so often termed, of the literary radio form are also extremely valuable examples of the significance of the form as a site of exploration of contemporary social issues, politics and cultural life in the mid-twentieth century. In 1969, a few years after the closure of the Features Department, producer Douglas Cleverdon reminded his readers that 'only a comparatively small proportion of the works produced by the BBC Features Department aimed at the highest standards of poetic achievement. Many of them were actualities, or topical documentaries, or critical features like the series of New Judgements' ${ }^{63}$ It feels like the time is approaching when we ought to be widening the lens on the feature form - as this volume strives to do in some respects. The existence of $\mathrm{BBC}$ Genome (the project which has put online the programme listings information for BBC radio and television from 1923 to 2009) makes preliminary mapping for such research projects more possible. The British Library's Sound Archive - the public point of on-request access to BBC recordings - is energetically seeking to preserve, especially through digitisation, archival recordings as part of its Save our Sounds programme. And the BBC is striving to make more of its archival riches - its own history - accessible in time for its centenary in 2022. It would be exciting to see, alongside these openings, the emergence of an inter-institutional, interdisciplinary scholarly network dedicated to writing in a collaborative way a fuller history of features to include the large body of work that may not have persisted in the schedules over the decades and may not have had a rich, intermedial afterlife, but which may, as part of a bigger tapestry, reveal significant insights into the social, political and cultural life of Britain in the middle decades of the twentieth century.

\section{Bibliography}


Addyman, D., M. Feldman, and E. Tonning, eds. Samuel Beckett and BBC Radio: A Reassessment. New York: Palgrave Macmillan, 2017.

Allison, Jonathan, ed. Letters of Louis MacNeice. London: Faber, 2010.

Anon. "A 'New Venture' ". The Listener, 16 January 1929, 14.

Anon. "Both Sides of the Microphone: Homeric 'Melodrama' ". Radio Times, 3 August $1945,5$.

Anon. "The Classics as Best-Sellers: Influence of Radio on Public Demand." The Times, 29 December 1952, 2.

Artmonsky, R. Art for the Ear: Forty Years of Illustration for BBC Radio Publications. London: Artmonsky Arts, 2015.

Backemeyer, S. Eric Fraser: Designer and Illustrator. London: Lund Humphries, 1998.

Briggs, A. The History of Broadcasting in the United Kingdom, Vol. 1: The Birth of Broadcasting. Oxford: Oxford University Press, 1961, rev. edn 1995.

Briggs, A. The History of Broadcasting in the United Kingdom, Vol. 2: The Golden Age of Wireless. Oxford: Oxford University Press, 1965, rev. edn 1995.

Cleverdon, D. The Growth of Milk Wood. London: Dent, 1969.

Cobb, S. "Adaptation, Fidelity, and Gendered Discourses." Adaptation 4.1 (2010): 28-37.

Cohen, D. R. "Intermediality and the Problem of the Listener." Modernism/modernity 19.3 (2012): 569-92.

Coulton, B. Louis MacNeice in the BBC. London: Faber, 1980.

De-la-Noy, M. Eddy: The Life of Edward Sackville-West, London: Arcadia, 1988.

Didi-Huberman, G., V. Rehberg, and B. Belay. "Artistic Survival: Panofsky vs. Warburg and the Exorcism of Impure Time." Common Knowledge 9.2 (2003): 273-85.

Gielgud, V. "A Festival of Radio Drama.” Radio Times, 4 May 1956, 3.

Gielgud, V. "Preface." In C. McGivern, Bomb Doors Open and Other Radio War Features, 7-10. London: Allen \& Unwin, 1941. 
Gielgud, V. "The Rescue." Radio Times, 22 February 1962, 50.

Gilliam, L. "Introduction." In his edited volume BBC Features, 9-14. London: BBC, 1950.

Gilliam, L., ed. BBC Features. London: BBC, 1950.

Granger, D. "Edinburgh Festival: Under Milk Wood". The Financial Times, 23 August 1956, 2.

Johnson, D. T. "Adaptation and Fidelity." In The Oxford Handbook of Adaptation Studies, edited by T. Leitch. Oxford: Oxford University Press, 2017.

Joicey, N. "A Paperback Guide to Progress: Penguin Books 1935-c. 1951." Twentieth Century British History 4.1 (1993): 25-56.

Lawrie, A. " 'The Appreciative Understanding of Good Books': The Listener, Literary Advice and the 1930s Reader." Literature \& History 24.2 (2015): 38-52.

Lipsey, R. The Spiritual in Twentieth-Century Art. Mineola, NY: Dover, 1988.

Lloyd, A. L., and I. Vinogradoff. Shadow of the Swastika: A Radio-Drama in Six Parts of the Story of the German National Socialist Party. London: Bodley Head, 1940.

McGivern, C. Bomb Doors Open and Other Radio War Features. London: Allen \& Unwin, 1941.

MacNeice, L. Christopher Columbus: A Radio Play. London: Faber, 1944.

MacNeice, L. The Dark Tower and Other Radio Scripts. London: Faber, 1947.

MacNeice, L. The Mad Islands and The Administrator: Two Radio Plays. London: Faber, 1964.

MacNeice, L. Persons from Porlock and Other Plays for Radio, with an Introduction by $W . H$. Auden. London: BBC, 1969.

Pegg, M. Broadcasting and Society, 1918-1939. London: Croom Helm, 1983.

Porter, A. "Riches Restored." The Observer, 16 April 1995.

Ratclyffe Dugmore, A. "Photographing Wild Animals." Radio Times, 28 September 1923, 3 and 5. 
Rodger, I. Radio Drama. London: Macmillan, 1982.

Sackville-West, E. "The Odyssey in Terms of Modern Radio." Radio Times, 19 November $1943,4$.

Sackville-West, E. The Rescue: A Melodrama for Broadcasting Based on Homer's Odyssey. Orchestral Score by Benjamin Britten. With Six Illustrations to the Text by Henry Moore. London: Secker \& Warburg, 1945.

Sherek, H. "Presenting Under Milk Wood." Radio Times, 3 May 1957, 7.

Tevnan, J. and T. Horsley. Norway Invaded: The First Full Story. London: Withy Grove Press, 1940.

Thomas, D. Quite Early One Morning. London: Dent, 1954.

Thomas, D. Under Milk Wood, edition by D. Jones. London: Dent, 1954.

Watkins, V. P. "Dylan Thomas and the Spoken Word." The Times Literary Supplement, 19 November 1954, 731.

Wrigley, A. and S. Harrison, eds. Louis MacNeice: The Classical Radio Plays. Oxford: Oxford University Press, 2013.

Wrigley, A. "Dylan Thomas' Under Milk Wood, 'a Play for Voices' on Radio, Stage and Television'. Critical Studies in Television 9.3 (2014), 77-88.

Wrigley, A. Greece on Air: Engagements with Ancient Greece on BBC Radio, 1920-1960s. Oxford: Oxford University Press, 2015.

\footnotetext{
${ }^{1}$ This essay is not closely associated with Warburgian Nachleben theory or subsequent critique (see, e.g., Didi-Huberman, Rehberg, and Belay, "Artistic Survival"); but it is open to the 'messiness' of history in its exploration of the circular movement, metamorphosis and experience of cultural works through time and across media. The related term 'afterlives' is therefore productive; certainly it is preferable to 'adaptation' which remains problematically bound up with language of fidelity (see Johnson, "Adaptation and Fidelity" and Cobb, "Adaptation, Fidelity, and Gendered Discourses").

${ }^{2}$ A recent example of the publication of archival sound is the 2006 distribution of the four-CD set Samuel Beckett: Works for Radio by the British Library, under licence from the $\mathrm{BBC}$ : these include his five pieces created for radio. On the formal categorisation of
} 
Beckett's radio works, see essays in Addyman, Feldman, and Tonning, eds, Samuel Beckett.

${ }^{3}$ Those uninterested in radio as a creative medium often locate radio writing at the periphery of literary figures' oeuvres; indeed, critics and obituary writers can be disparaging of writing for the medium. For the range of estimations of MacNeice's radio work in relation to his poetry, see discussion in Wrigley and Harrison, eds, Louis MacNeice, 4-5.

${ }^{4}$ Wrigley and Harrison, eds, Louis MacNeice, sought to fill in some of this picture; much territory remains to be explored.

${ }^{5}$ Anon., "The Classics as Best-Sellers."

${ }^{6}$ On Radio Times artwork see, e.g. Artmonsky, Art for the Ear, and Backemeyer, Eric

Fraser. See Briggs, The Birth of Broadcasting, $270 \mathrm{ff}$. on the way Radio Times shaped the BBC's public image.

${ }^{7}$ Ratclyffe Dugmore, "Photographing."

${ }^{8}$ Briggs, The Golden Age, $260 \mathrm{ff}$.

${ }^{9}$ Anon., "A 'New Venture' ". On printed talks in The Listener, see Cohen, "Intermediality", 575; and on the periodical's encouragement of readers to expand their literary horizons, see Lawrie, " "The Appreciative Understanding' ".

${ }^{10}$ Briggs, The Golden Age, 269.

${ }^{11}$ On Penguin Classics and radio, see Wrigley, Greece on Air, 94-7.

${ }^{12}$ Details in BBC WAC, Talks, Allen Lane, file 1, 1939-62.

${ }^{13}$ Quoted in Joicey, "A Paperback Guide", 30.

${ }^{14}$ Briggs, The Birth of Broadcasting, 16, quoting a report written by a Lincoln librarian.

${ }^{15}$ Pegg, Broadcasting, 209 and 211.

${ }^{16}$ Coulton, Louis MacNeice, 161-2.

${ }^{17}$ Gilliam, ed., BBC Features, flyleaf.

${ }^{18}$ Gilliam, "Introduction", 13. The permanence of print is described as desirable also by Gielgud, "Preface."

${ }^{19}$ British Justice was adapted for television presentation in the same year.

${ }^{20}$ MacNeice, The Dark Tower, 9 and 13.

${ }^{21}$ MacNeice, The Dark Tower, 9.

${ }^{22}$ MacNeice, Christopher Columbus, 7. MacNeice admits that before becoming a BBC writer and producer in wartime, he had ('like most of the intelligentsia') been prejudiced against the medium (MacNeice, The Dark Tower, 11). See Rodger, Radio Drama, 5-8 on the intellectual bias against radio, and radio drama in particular.

${ }^{23}$ MacNeice, Christopher Columbus, 8.

${ }^{24}$ MacNeice, Christopher Columbus, 10.

${ }^{25}$ MacNeice, Christopher Columbus, 18.

${ }^{26}$ MacNeice, The Dark Tower, 17.

${ }^{27}$ Sackville-West, The Rescue, 16.

${ }^{28}$ On the term 'listen in', see Briggs, The Birth of Broadcasting, 222.

${ }^{29}$ Sackville-West, "The Odyssey." 
${ }^{30}$ But on the antagonism amongst some BBC staff towards Britten's conscientious objection to active service, which appears to have kept him from being able to conduct his own music for the 1943 production, see Wrigley, Greece on Air, 191-192.

${ }^{31}$ Sackville-West, "The Odyssey."

${ }^{32}$ Sackville-West, The Rescue, 12-13.

${ }^{33}$ Sackville-West, The Rescue, 35, 46 and 96.

${ }^{34}$ Anon., "Both Sides."

${ }^{35}$ Lipsey, The Spiritual, 290. For analysis, see Wrigley, Greece on Air, 205-206.

${ }^{36}$ Gielgud, "A Festival."

${ }^{37}$ De-la-Noy, Eddy.

${ }^{38}$ Porter, "Riches Restored."

${ }^{39}$ MacNeice, The Dark Tower, 20 (dedication) and 22.

${ }^{40}$ MacNeice is reworking Robert Browning's nineteenth-century poem 'Childe Roland to the Dark Tower Came' (the title of which is from King Lear, Act 3, scene 4), which focuses on the struggles of an untested medieval knight as he journeys to the Dark Tower where he will die. Browning's poem has inspired many reworkings.

${ }^{41}$ MacNeice, The Dark Tower, 21 and 22.

${ }^{42}$ MacNeice was in Italy in 1947 gathering material for his feature Portrait of Rome (memo from George R. Foa to several people including Laurence Gilliam and Louis MacNeice, 1 June 1947, 3, in BBC WAC R19/953).

${ }^{43}$ The precise number of scripts he wrote is unknown: see Wrigley and Harrison, eds, Louis MacNeice, 1 n. 2 on various estimations.

${ }^{44}$ Letter from MacNeice to Eliot, 27 August 1942, in Allison, ed., Letters, 445-6 (446).

${ }^{45}$ Letter from MacNeice to Eliot, 16 October 1945, in Allison, ed., Letters, 461-2 (461, 462).

${ }^{46}$ Letter from MacNeice to Monteith, 21 March 1962, in Allison, ed., Letters, 690.

${ }^{47}$ See https://snapemaltings.co.uk/whats-on/the-dark-tower (last accessed 10 January 2018).

${ }^{48}$ MacNeice, The Mad Islands; MacNeice, Persons from Porlock, 7.

${ }^{49}$ Wrigley and Harrison, eds, Louis MacNeice.

${ }^{50}$ Sherek, "Presenting Under Milk Wood." On the stage and television versions, see

Wrigley, "Dylan Thomas' Under Milk Wood."

${ }^{51}$ Watkins, "Dylan Thomas," reviewing Thomas, Quite Early One Morning.

${ }^{52}$ Cleverdon, The Growth of Milk Wood, 1.

${ }^{53}$ Cleverdon, The Growth of Milk Wood, flyleaf.

${ }^{54}$ Wrigley, "Dylan Thomas' Under Milk Wood."

${ }^{55}$ Granger, "Edinburgh Festival."

${ }^{56}$ Rodger, Radio Drama, 157.

${ }^{57}$ MacNeice, Christopher Columbus, 10.

${ }^{58}$ MacNeice, Christopher Columbus, 18.

${ }^{59}$ Rodger, Radio Drama, 155-6. 
${ }^{60}$ Today's scholar is happy to be able to purchase reasonably priced first editions in secondhand bookshops, especially in instances where recordings have been lost or are inaccessible.

${ }^{61}$ 'Early Radio Features' (British Library, 2014), co-curated by Amanda Wrigley and Hugh Chignell with the invaluable support of Radio Curator Paul Wilson and in collaboration with In the Dark. My 2016 series, 'Louis MacNeice, Radio Writer and Producer', aimed to bring some of his lesser-known work into the public domain.

${ }^{62}$ Gielgud, "The Rescue."

${ }^{63}$ Cleverdon, The Growth of Milk Wood, 8. 